We are extremely grateful to $\mathrm{Mr} \mathrm{H} \mathrm{E} \mathrm{Lockhart-Mummery} \mathrm{and}$ Mr B T Jackson for allowing us to include some of their patients in this trial and to the Trustees of St Thomas's Hospital Charitable Trust who have given us generous financial support.

\section{References}

${ }^{1}$ Negus, D, et al, British fournal of Surgery, 1968, 55, 835.

2 Williams, O, et al, British Medical fournal, 1974, 1, 600.
${ }^{3}$ McNeal, B J, Holman, B L, and Adelstein, S J, fournal of the American Medical Association, 1974, 227, 753.

4 Croft, D N, British fournal of Radiology, 1976, 49, 470.

5 Croft, D N, European fournal of Nuclear Medicine, 1976, 1, 85.

${ }^{6}$ Freiman, D G, Sugemoto, J, and Wessler, S, New England fournal of Medicine, 1965, 272, 1278.

7 Coon, W W, and Coller, F A, Surgery, Gynaecology and Obstetrics, 1959, $109,487$.

${ }^{8}$ Allison, P R, Dunnill, M S, and Marshall, R, Thorax, 1960, 15, 273.

9 Browse, N L, Clemenson, G, and Croft, D N, British Medical fournal, 1974, 1, 603.

${ }^{10}$ Kline, A, et al, British Medical fournal, 1975, 2, 109.

\title{
Tobramycin, amikacin, sissomicin, and gentamicin resistant Gram-negative rods
}

\author{
F A DRASAR, W FARRELL, J MASKELL, J D WILLIAMS
}

British Medical fournal, 1976, 2, 1284-1287

\section{Summary}

Sensitivities to gentamicin, sissomicin, tobramycin, and amikacin were compared in 196 gentamicin-resistant Gram-negative rods and in 212 similar organisms sensitive to gentamicin, mainly isolated from clinical specimens. Amikacin was the aminoglycoside most active against gentamicin-resistant organisms, Pseudomonas aeruginosa, Klebsiella spp, Escherichia coli, Proteus spp, Providencia spp, and Citrobacter spp being particularly susceptible. Most of the gentamicin-resistant organisms were isolated from the urine of patients undergoing surgery.

Gentamicin was the most active antibiotic against gentamicin-sensitive $E$ coli, Proteus mirabilis, and Serratia spp. Pseudomonas aeruginosa and other Pseudomonas spp were most susceptible to tobramycin.

\section{Introduction}

Since 1964 gentamicin has proved valuable in treating severe infections caused by Pseudomonas spp, Enterobacteria, and related Gram-negative rods resistant to gentamicin. ${ }^{1-4}$ In one hospital in Los Angeles $20 \%$ of clinical isolates of Pseudomonas aeruginosa and $50 \%$ of Serratia marcescens isolates were resistant to gentamicin ${ }^{5}$ and $20 \%$ of Gram-negative rods isolated from sputum and blood in a group of hospitals in Japan were resistant to gentamicin. ${ }^{6}$

Gentamicin-resistant organisms have been isolated with increasing frequency at the London Hospital, and we have collected these strains to determine susceptibility to tobramycin, sissomicin, and amikacin. We also compared the activity of the four aminoglycosides against Gram-negative rods sensitive to gentamicin.

\footnotetext{
Department of Medical Microbiology, London Hospital Medical College, London E1

F A DRASAR, PHD, MRCPATH, senior lecturer in microbiology

W FARRELL, FIMLT, senior technician

J MASKELL, AIST, technician

J D WILLIAMS, MD, MRCPATH, professor of medical microbiology
}

\section{Methods}

One hundred and ninety-six strains of enterobacteria, $P_{s}$ aeruginosa and other Pseudomonas spp, Acinetobacter spp, Alcaligenes spp, and Flavobacterium spp isolated from clinical specimens and which seemed to be resistant to gentamicin using a 10- $\mu \mathrm{g}$ disc were collected over 18 months. Four strains of gentamicin-resistant organisms from environmental sources were included. Another 212 strains of similar organisms sensitive to gentamicin by disc testing were collected over three months.

The minimum inhibitory concentrations (MIC) of gentamicin, sissomicin, tobramycin, and amikacin were measured by the agar dilution technique using doubling dilutions of the antibiotic in DST

TABLE I-Numbers of different species of gentamicin-resistant Gram-negative rods

\begin{tabular}{l|c||l|c}
\hline & $\begin{array}{c}\text { No of } \\
\text { species }\end{array}$ & & $\begin{array}{c}\text { No of } \\
\text { species }\end{array}$ \\
\hline Providencia spp & 35 & Indole-positive Proteus & 11 \\
Ps aeruginosa & 32 & Pseudomonas spp & 8 \\
Acinetobacter spp & 27 & Klebsiella spp & 8 \\
Enterobacter spp & 25 & E coli & 7 \\
Alcaligenes spp & 14 & Flavobacterium spp & 7 \\
K aerogenes & 13 & Others & 9 \\
\hline
\end{tabular}

TABLE II-Specimens containing Gram-negative rods resistant to gentamicin*

\begin{tabular}{l|c||l|c}
\hline & $\begin{array}{c}\text { No of } \\
\text { specimens }\end{array}$ & $\begin{array}{c}\text { No of } \\
\text { specimens }\end{array}$ \\
\hline Urine & 119 & Pleural fluid & 5 \\
Wound swabs & 26 & Dialysis fluid & 4 \\
Sputum & 18 & Environment & 4 \\
Ear swabs & 13 & CSF & 1 \\
\hline
\end{tabular}

*For 6 specimens the sources were unknown

TABLE III-Numbers of gentamicin-resistant Gram-negative rods occurring in different sites in the London Hospital*

\begin{tabular}{l|c||c|c}
\hline & $\begin{array}{c}\text { No of } \\
\text { isolates }\end{array}$ & $\begin{array}{c}\text { No of } \\
\text { isolates }\end{array}$ \\
\hline Medical wards & 34 & $\begin{array}{c}\text { Surgical wards: } \\
\text { Renal }\end{array}$ & 110 \\
Outpatient clinics: & 25 & $\begin{array}{c}\text { Neurosurgery } \\
\text { ENT }\end{array}$ & 26 \\
Surgical & 8 & Intensive therapy & 12 \\
Dermatology & 5 & & \\
\hline
\end{tabular}

*For 27 isolates the sources were unknown 
agar (Oxoid). An inoculum of about $10^{3} \log$ phase bacteria suspended in peptone water was applied to the plates using a multipoint inoculator.

Organisms with an MIC of gentamicin of $8 \mu \mathrm{g} / \mathrm{ml}$ or greater were defined as being resistant. This level was chosen since lower serum concentrations of gentamicin can be maintained throughout most of the treatment of patients suffering from life-threatening infections caused by Gram-negative rods. Sensitive organisms were defined as having an MIC to gentamicin $\leqslant 4 \mu \mathrm{g} / \mathrm{ml}$. The distribution of gentamicin-resistant strains in the hospital were studied.

\section{Results}

EPIDEMIOLOGY OF GENTAMICIN-RESISTANT ORGANISMS

Table I shows the range of gentamicin-resistant organisms and the number of isolates of each particular species. Providencia spp, Ps

TABLE IV-Amount of gentamicin used in London Hospital from 1972-5

\begin{tabular}{c|c|c|c|c|c} 
& & \multicolumn{2}{c|}{ Gentamicin (g) used } & & \\
Year & Injectable & Drops & Ointments & Powder & \\
\hline 1972 & 320 & 10 & 45 & 15 & 390 \\
1973 & 540 & 7 & 12 & 6 & 565 \\
1974 & 560 & 5 & 31 & 3 & 599 \\
1975 & 760 & 4 & 27 & 9 & 800 \\
\hline
\end{tabular}

aeruginosa, Acinetobacter spp, and Enterobacter spp were the most common organisms. "Other species" included one strain of $S$ marcescens and four strains each of Citrobacter freundii and Proteus mirabilis. The isolation rate of some species was not constant over the 18 months of collection. Most Ps aeruginosa strains were collected over the first six months, most Providencia spp over the second six months, and most Enterobacter spp only over the last six months.

Specimens yielding gentamicin-resistant organisms are shown in table II. Most isolates came from catheter or midstream specimens of urine, and only 26 strains came from the next most common source -wound swabs. The four environmental specimens were samples of water from Winchester bottles used for 24-hour urine collection on the renal ward.

Table III shows the distribution of gentamicin-resistant bacteria in the London Hospital. The isolation rate from surgical wards was over three times that from medical wards. The three main surgical areas affected are shown.

Gentamicin-resistant Gram-negative rods amounted to $1-2 \%$ of all Gram-negative rods isolated in this hospital; this represented at least a twofold increase over the previous 18 months. The incidence varied considerably between species. For instance, the overall resistance of Ps aeruginosa was around 5\%, of Klebsiella and Enterobacter spp 7\%, of Acinetobacter spp $20 \%$, and of Alkaligines spp $25 \%$. E coli and $P$ mirabilis had a very low incidence of gentamicin resistance (around $0 \cdot 1 \%$ ). Providencia spp and Flavobacterium spp isolated from this hospital were invariably resistant to gentamicin.

The use of parenteral gentamicin has more than doubled over the last four years (table IV). The most gentamicin is used in the three

TABLE V-MICs of gentamicin, sissomicin, tobramycin and amikacin for Gram-negative rods resistant to gentamicin

\begin{tabular}{|c|c|c|c|c|c|c|c|c|c|c|c|c|c|}
\hline \multirow{2}{*}{ Species } & \multirow{2}{*}{$\begin{array}{l}\text { No of } \\
\text { strains }\end{array}$} & \multirow{2}{*}{ Antibiotic } & \multicolumn{11}{|c|}{ No of strains with MICs $(\mu \mathrm{g} / \mathrm{ml})$ of: } \\
\hline & & & 0.5 & 1 & 2 & 4 & 8 & 16 & 32 & 64 & 128 & 256 & $>256$ \\
\hline Ps aeruginosa & 32 & $\begin{array}{l}\mathbf{G} \\
\mathbf{S} \\
\mathbf{T} \\
\mathbf{A}\end{array}$ & 1 & $\begin{array}{l}7 \\
6 \\
5\end{array}$ & $\begin{array}{r}3 \\
10 \\
7\end{array}$ & $\begin{array}{l}4 \\
7 \\
1\end{array}$ & $\begin{array}{l}8 \\
8 \\
6 \\
6\end{array}$ & $\begin{array}{l}5 \\
5 \\
2 \\
8\end{array}$ & $\begin{array}{l}3 \\
3 \\
2\end{array}$ & $\begin{array}{l}4 \\
2 \\
1\end{array}$ & $\begin{array}{l}7 \\
2\end{array}$ & 2 & 3 \\
\hline Pseudomonas spp & 8 & $\begin{array}{l}\mathrm{G} \\
\mathbf{S} \\
\mathbf{T} \\
\mathbf{A}\end{array}$ & & & 1 & $\begin{array}{l}3 \\
4\end{array}$ & $\begin{array}{l}2 \\
1 \\
1 \\
1\end{array}$ & $\begin{array}{l}1 \\
2\end{array}$ & $\begin{array}{l}1 \\
1\end{array}$ & $\begin{array}{l}1 \\
2\end{array}$ & $\begin{array}{l}3 \\
1\end{array}$ & 1 & $\begin{array}{l}2 \\
1 \\
2 \\
1\end{array}$ \\
\hline$K$ aerogenes & 13 & $\begin{array}{l}\mathrm{G} \\
\mathbf{S} \\
\mathbf{T} \\
\mathbf{A}\end{array}$ & & $\begin{array}{l}1 \\
7\end{array}$ & 3 & 1 & $\begin{array}{l}6 \\
3 \\
4 \\
1\end{array}$ & $\begin{array}{l}3 \\
6 \\
4 \\
1\end{array}$ & $\begin{array}{l}1 \\
1 \\
2 \\
1\end{array}$ & 1 & & 1 & $\begin{array}{l}3 \\
2\end{array}$ \\
\hline Klebsiella spp & 8 & $\begin{array}{l}\text { G } \\
\mathbf{S} \\
\mathbf{T} \\
\mathbf{A}\end{array}$ & & $\begin{array}{l}1 \\
2\end{array}$ & 1 & $\begin{array}{l}1 \\
4 \\
2\end{array}$ & $\begin{array}{l}1 \\
1\end{array}$ & $\begin{array}{l}2 \\
1 \\
2 \\
1\end{array}$ & $\begin{array}{l}1 \\
1 \\
1\end{array}$ & 1 & $\begin{array}{l}3 \\
1\end{array}$ & $\begin{array}{l}2 \\
2\end{array}$ & $\begin{array}{l}1 \\
1\end{array}$ \\
\hline$E$ coli & 7 & $\begin{array}{l}\mathbf{G} \\
\mathbf{S} \\
\mathbf{T} \\
\mathbf{A}\end{array}$ & & 4 & & 1 & 1 & $\begin{array}{l}3 \\
3 \\
2\end{array}$ & $\begin{array}{l}1 \\
4 \\
1\end{array}$ & 1 & $\begin{array}{l}1 \\
1\end{array}$ & $\begin{array}{l}2 \\
3\end{array}$ & \\
\hline Serratia spp & 1 & $\begin{array}{l}\mathrm{G} \\
\mathbf{S} \\
\mathrm{T} \\
\mathrm{A}\end{array}$ & & & & & 1 & $\begin{array}{l}1 \\
1 \\
1\end{array}$ & & & & & \\
\hline Enterobacter spp & 25 & $\begin{array}{l}\mathbf{G} \\
\mathbf{S} \\
\mathbf{T} \\
\mathbf{A}\end{array}$ & 1 & 24 & & & & 2 & 20 & 3 & $\begin{array}{l}2 \\
2\end{array}$ & 17 & $\begin{array}{r}23 \\
6\end{array}$ \\
\hline Citrobacter spp & 4 & $\begin{array}{l}\text { G } \\
\mathbf{S} \\
\mathbf{T} \\
\mathrm{A}\end{array}$ & & 4 & & & & & 3 & 1 & & 4 & 4 \\
\hline Indole-positive Proteus & 11 & $\begin{array}{l}\mathbf{G} \\
\mathbf{S} \\
\mathbf{T} \\
\mathbf{A}\end{array}$ & & 2 & 2 & 2 & $\begin{array}{l}3 \\
4\end{array}$ & $\begin{array}{l}2 \\
3 \\
1\end{array}$ & $\begin{array}{l}1 \\
\mathbf{4} \\
1\end{array}$ & $\begin{array}{l}3 \\
2 \\
2\end{array}$ & $\begin{array}{l}3 \\
1 \\
1\end{array}$ & $\begin{array}{l}2 \\
2 \\
1\end{array}$ & 1 \\
\hline$P$ mirabilis & 4 & $\begin{array}{l}\mathrm{G} \\
\mathbf{S} \\
\mathbf{T} \\
\mathbf{A}\end{array}$ & & 2 & & 1 & 1 & $\begin{array}{l}1 \\
1 \\
1\end{array}$ & $\begin{array}{l}1 \\
2 \\
2\end{array}$ & $\begin{array}{l}2 \\
1\end{array}$ & 1 & & $\cdot$ \\
\hline Providencia spp & 35 & $\begin{array}{l}\mathbf{G} \\
\mathbf{S} \\
\mathbf{T} \\
\mathbf{A}\end{array}$ & & 6 & $\begin{array}{r}1 \\
10\end{array}$ & $\begin{array}{l}4 \\
4\end{array}$ & $\begin{array}{r}1 \\
2 \\
10\end{array}$ & $\begin{array}{r}10 \\
4 \\
9 \\
2\end{array}$ & $\begin{array}{r}6 \\
12 \\
6 \\
1\end{array}$ & $\begin{array}{l}4 \\
2 \\
5\end{array}$ & $\begin{array}{l}4 \\
4 \\
2\end{array}$ & $\begin{array}{l}4 \\
9 \\
3\end{array}$ & $\begin{array}{l}6 \\
8 \\
1\end{array}$ \\
\hline Acinetobacter spp & 27 & $\begin{array}{l}\mathbf{G} \\
\mathbf{S} \\
\mathbf{T} \\
\mathbf{A}\end{array}$ & & & $\begin{array}{l}1 \\
2 \\
3\end{array}$ & $\begin{array}{l}6 \\
5\end{array}$ & $\begin{array}{l}1 \\
1\end{array}$ & $\begin{array}{l}6 \\
2 \\
3\end{array}$ & $\begin{array}{l}\mathbf{5} \\
\mathbf{8} \\
\mathbf{3} \\
\mathbf{3}\end{array}$ & $\begin{array}{l}3 \\
5 \\
3 \\
4\end{array}$ & $\begin{array}{l}2 \\
3 \\
2 \\
3\end{array}$ & $\begin{array}{l}4 \\
2 \\
4 \\
4\end{array}$ & $\begin{array}{l}7 \\
6 \\
3 \\
4\end{array}$ \\
\hline Alcaligenes spp & 14 & $\begin{array}{l}\mathbf{G} \\
\mathbf{S} \\
\mathbf{T} \\
\mathbf{A}\end{array}$ & & & & $\begin{array}{l}1 \\
2\end{array}$ & $\begin{array}{l}1 \\
1 \\
2\end{array}$ & $\begin{array}{l}1 \\
2 \\
3\end{array}$ & 3 & $\begin{array}{l}1 \\
3 \\
2\end{array}$ & $\begin{array}{l}2 \\
1 \\
1 \\
1\end{array}$ & $\begin{array}{l}2 \\
3 \\
1 \\
1\end{array}$ & $\begin{array}{l}7 \\
5 \\
4 \\
6\end{array}$ \\
\hline Flavobacterium spp & 7 & $\begin{array}{l}\mathbf{G} \\
\mathbf{S} \\
\mathbf{T} \\
\mathbf{A}\end{array}$ & & & & & & & & 2 & $\begin{array}{l}4 \\
3\end{array}$ & $\begin{array}{l}2 \\
1 \\
1\end{array}$ & $\begin{array}{l}1 \\
6 \\
7 \\
1\end{array}$ \\
\hline
\end{tabular}


surgical wards listed in table III as having the highest yield of gentamicin-resistant Gram-negative rods.

\section{MICS OF GENTAMICIN-RESISTANT BACTERIA}

The MICs of gentamicin, sissomicin, tobramycin, and amikacin are shown in table $\mathrm{V}$. The percentage of strains of gentamicin-resistant organisms with MICs of $8 \mu \mathrm{g} / \mathrm{ml}$ to tobramycin and sissomicin or MICs of $16 \mu \mathrm{g} / \mathrm{ml}$ to amikacin is shown in table VI. The level of 8 or $16 \mu \mathrm{g} / \mathrm{ml}$ were chosen as lower serum levels may be attained throughout most of a course of treatment with these antibiotics. This gives some indication of the in-vitro "susceptibility" or "resistance" of the organisms.

All strains of indole-positive Proteus spp, Enterobacter spp, and Citrobacter spp were sensitive only to amikacin. Amikacin was the most active antibiotic against $E$ coli, $K$ aerogenes, Providencia spp, Klebsiella spp, and Ps aeruginosa, although tobramycin showed considerable activity over the latter two groups. Alcaligenes spp and Acinetobacter spp were seldom sensitive to any of the aminoglycosides studied and Flavobacterium spp were constantly resistant to all the antibiotics. Sissomicin showed little activity against any of the organisms studied and was most active against Ps aeruginosa, $44 \%$ of these being susceptible.

TABLE VI-Susceptibility of gentamicin-resistant Gram-negative rods to sissomicin, tobramycin, and amikacin

\begin{tabular}{|c|c|c|c|c|}
\hline \multirow{2}{*}{ Species } & \multirow{2}{*}{$\begin{array}{l}\text { No of } \\
\text { strains }\end{array}$} & \multicolumn{3}{|c|}{$\begin{array}{c}\% \text { Susceptible to various concentrations } \\
\text { of antibiotics }\end{array}$} \\
\hline & & $\begin{array}{l}\text { Sissomicin } \\
(8 \mu \mathrm{g} / \mathrm{ml})\end{array}$ & $\begin{array}{l}\text { Tobramycin } \\
(8 \mu \mathrm{g} / \mathrm{ml})\end{array}$ & $\begin{array}{l}\text { Amikacin } \\
(16 \mu \mathrm{g} / \mathrm{ml})\end{array}$ \\
\hline $\begin{array}{l}\text { Ps aeruginosa } \\
\text { Pseudomonas spp } \\
\text { K aerogenes } \\
\text { Klebsiella spp } \\
\text { E coli } \\
\text { Serratia spp } \\
\text { Enterobacter spp } \\
\text { Citrobacter spp } \\
\text { Indole-positive Proteus } \\
\text { P mirabilis } \\
\text { Providencia } \mathrm{spp} \\
\text { Acinetobacter spp } \\
\text { Alcaligenes spp } \\
\text { Flavobacterium spp }\end{array}$ & $\begin{array}{r}32 \\
8 \\
13 \\
8 \\
7 \\
1 \\
25 \\
4 \\
11 \\
4 \\
35 \\
27 \\
14 \\
7\end{array}$ & $\begin{array}{r}44 \\
40 \\
0 \\
12 \\
0 \\
0 \\
0 \\
0 \\
0 \\
0 \\
0 \\
4 \\
7 \\
0\end{array}$ & $\begin{array}{r}75 \\
57 \\
15 \\
50 \\
0 \\
0 \\
0 \\
0 \\
0 \\
0 \\
14 \\
30 \\
14 \\
0\end{array}$ & $\begin{array}{r}85 \\
40 \\
94 \\
75 \\
72 \\
100 \\
100 \\
100 \\
100 \\
75 \\
92 \\
33 \\
22 \\
0\end{array}$ \\
\hline
\end{tabular}

TABLE VII-Mode MICs of gentamicin, sissomicin, tobramycin, and amikacin for gentamicin-sensitive Gram-negative rods

\begin{tabular}{|c|c|c|c|c|c|}
\hline \multirow{2}{*}{ Species } & \multirow{2}{*}{$\begin{array}{l}\text { No of } \\
\text { strains }\end{array}$} & \multicolumn{4}{|c|}{ Mode MIC $(\mu \mathrm{g} / \mathrm{ml})$ to: } \\
\hline & & Gentamicin & Sissomicin & Tobramycin & Amikacin \\
\hline $\begin{array}{l}\text { Ps aeruginosa } \\
\text { Pseudomonas spp } \\
\text { E coli } \\
\text { Kaerogenes } \\
\text { Klebsiella spp } \\
\text { Enterobacter spp } \\
\text { P mirabilis } \\
\text { Indole-positive Proteus } \\
\text { Serratia spp } \\
\text { Citrobacter spp } \\
\text { Acinetobacter spp }\end{array}$ & $\begin{array}{r}17 \\
7 \\
52 \\
19 \\
16 \\
18 \\
32 \\
23 \\
7 \\
14 \\
7\end{array}$ & $\begin{array}{l}1 \\
1 \\
0.5 \\
0.5 \\
0.5 \\
0.5 \\
0.5 \\
0.5 \\
0.5 \\
0.5 \\
0.5\end{array}$ & $\begin{array}{l}1 \\
2 \\
1 \\
0 \cdot 5 \\
1 \\
1 \\
1 \\
1 \\
2 \\
1 \\
1\end{array}$ & $\begin{array}{l}0.25 \\
0.50 \\
1 \\
0.5 \\
0.5 \\
0.5 \\
1 \\
0.5 \\
2.5 \\
0.5 \\
0.5\end{array}$ & $\begin{array}{l}2 \\
4 \\
2 \\
1 \\
1 \\
1 \\
2 \\
1 \\
2 \\
1 \\
2\end{array}$ \\
\hline
\end{tabular}

\section{GENTAMICIN-SENSITIVE BACTERIA}

The mode MICs for the main groups of gentamicin-sensitive organisms is shown in table VII. Tobramycin was more active against Ps aeruginosa and Pseudomonas spp than the three other aminoglycosides. Gentamicin was marginally more active against $E$ coli, Proteus mirabilis, and Serratia spp, but the MICs of gentamicin and tobramycin against other species were comparable. The MICs of sissomicin and amikacin were generally higher than those of gentamicin.

\section{Discussion}

The MIC of gentamicin for most enterobacteria is in the range of $0.5-2 \mu \mathrm{g} / \mathrm{ml}$ and for Ps aeruginosa is slightly higher at $0.5-4$ $\mu \mathrm{g} / \mathrm{ml} .^{7}$ Tobramycin has been reported to be two to four times more active than gentamicin against $P$ s aeruginosa. ${ }^{8}$ Our results with gentamicin-sensitive organisms agree with this finding, but there are differing reports from other laboratories on the activity of sissomicin and amikacin. Sissomicin is said to be more active 3 than gentamicin or tobramycin against $E$ coli, ${ }^{9}$ but inferior $\stackrel{\mathbb{Q}}{\Omega}$ activity has been reported by another group. ${ }^{10}$ Serratia spp have $C$ been said to be most sensitive to sissomicin ${ }^{11}$ and amikacin. ${ }^{12} \overrightarrow{\bar{B}}$ This wide divergence in results from different groups may reflect $\stackrel{0}{\rightarrow}$ differences in techniques or even a difference in strains isolated from various sources.

We found that gentamicin was most active against all $\frac{\omega}{\vec{D}}$ gentamicin-sensitive rods except Pseudomonas spp, which were $\cong$ more sensitive to tobramycin. Gentamicin seems to be suitable कै for treating infections caused by these organisms, with the $\vec{\circ}$ possible exception of pseudomonal infections, which might respond more rapidly to tobramycin.

Sissomicin MICs were generally higher than those of gentamicin and since attainable serum levels of these two antibiotics are similar there seems little point in choosing sissomicin.

The amikacin MICs were generally two to four times greater 8 than those for gentamicin, but amikacin is a kanamycin derivative and much higher serum levels can be maintained with relatively few toxic effects. ${ }^{13}$ Both ototoxic and nephrotoxic effects have $\infty$ been reported, however, although such effects are mainly linked $\stackrel{+}{\circ}$ with particularly high doses or prolonged courses of amikacin. ${ }^{13} 14 \mathrm{~J}$ Further clinical trials are required to compare the therapeutic $N$ efficacy and toxic effects of amikacin with those of other $Z$ aminoglycosides. Amikacin has been reported to be active against gentamicin-resistant $P$ s aeruginosa, Providencia spp, and $S \stackrel{\Phi}{3}$ marcescens $5^{15}$ and showed considerable activity against our $\mathcal{D}_{\mathbb{D}}$ gentamicin-resistant Gram-negative rods. Clinical trials with amikacin have given promising results, ${ }^{13}{ }^{16}$ and this antibiotic $\vec{\varphi}$ may have a place in future chemotherapy, especially if infections with gentamicin-resistant organisms become more common.

The high activity of amikacin against these resistant organisms can be explained by its low susceptibility to enzyme degradation. The ability to produce these aminoglycoside-inactivating enzymes is controlled by plasmids which may be passed to $\mathbb{D}$ gentamicin-sensitive Gram-negative rods during bacterial $\overrightarrow{\vec{P}}$ conjugation. While gentamicin and sissomicin are susceptible to $\frac{0}{3}$ five enzymes and tobramycin to four, amikacin is inactivated by only one of these enzymes. ${ }^{17}$

The isolation rate of gentamicin-resistant Gram-negative rods is increasing in this hospital in parallel with the increased use of parenteral gentamicin. Areas where the most gentamicin is used yield most resistant organisms. There have been reports ${ }^{18}$ of resistance developing in bacteria in patients on gentamicin treatment but we have had no experience of this. Several patients acquired resistant organisms during treatment but the infections were such that these organisms might have been introduced 은 from the environment or might have been selected by treatment $\tilde{N}$ with gentamicin.

We cannot explain the many Ps aeruginosa and Providencia spp organisms isolated in the first and second six-monthly periods. Both groups of organisms occurred in widely separated N areas of the hospital and the Pseudomonas strains belonged to $\omega$ several pyocine types. Many of the Enterobacter spp isolated in the last six-months occurred in one area of the hospital, indicating possible cross-infection.

Gentamicin-resistant Gram-negative rods are becoming more numerous in many hospitals. Although many of the infections caused by our strains were relatively mild, these organisms are $\mathbb{\nabla}$ available as a source of infection for groups at risk. They may $\frac{\rho}{\mathbb{D}}$ also colonise the environment and may exist as a potentially dangerous reservoir of infection. Many of these infections may be susceptible to treatment with amikacin, but the problem of $\delta$ treating infections caused by gentamicin-resistant Flavobacterium spp, Acinetobacter spp, and Alcaligenes spp remains unsolved.

We thank the staff in the clinical laboratory who collected the strains for us. Sissomicin was kindly provided by Bayer UK Limited, amikacin by Bristol Laboratories, and tobramycin by Lilly Research. 


\section{References}

${ }^{1}$ Martin, C M, et al, fournal of Infectious Diseases, 1971, 124, suppl P 24.

2 Roe, E, and Lowbury, E J L, Fournal of Clinical Pathology, 1972, 25, 176.

3 Inamatsu, T, Nakauchi, K, and Shimada, K, Proceedings of the 9th International Congress of Chemotherapy, 1976, in press.

${ }^{4}$ Daikos, G K, et al, in Proceedings of the 8th International Congress of Chemotherapy, ed G K Daikos, vol 1, p 427. Athens, Hellenic Society for Chemotherapy, 1973.

5 Meyer, R D, et al, Lancet, 1976, 1, 580.

${ }_{6}$ Tomioka, S, Kobayashi, Y, and Hasegawa, M, Proceedings of the 9 th International Congress of Chemotherapy, 1976, in press.

7 Garrod, L P, Lambert, H P, and O'Grady, F, Antibiotic and Chemotherapy, 4th edn, p 116. London, Churchill Livingstone, 1973.

${ }^{8}$ Waterworth, P M, fournal of Clinical Pathology, 1972, 25, 979.

9 Waitz, J A, et al, Antimicrobial Agents and Chemotherapy, 1972, 2, 431.
${ }^{10}$ Klastersky, J, et al, European fournal of Cancer, 1973, 9, 641.

${ }^{11}$ Crowe, C C, and Sanders, E, Antimicrobial Agents and Chemotherapy, $1973,3,24$

12 Weinstein, R J, Young, L S, and Hewitt, W L, Antimicrobial Agents and Chemotherapy, 1975, 7, 172.

13 Valdivieso, M, et al, Proceedings of the 9th International Congress of Chemotherapy, 1976, in press.

${ }^{14}$ Meyer, R D, et al, Annals of Internal Medicine, 1975, 83, 790.

15 Reynolds, A V, Hamilton-Miller, J M T, and Brumfitt, W, British Medical fournal, 1974, 3, 778 .

${ }^{16}$ Haldane, E B, and van Rooyen, C E, Proceedings of the 9th International Congress of Chemotherapy, 1976, in press.

17 Price, K E, Godfrey, J C, and Kawaguchi, H, Advances in Applied Microbiology, 1974, 18, 191.

18 George, R H, and Heding, D E, Lancet, 1976, 1, 258.

\title{
Hypertension after renal transplantation
}

\author{
C BACHY， G P J ALEXANDRE，C VAN YPERSELE DE STRIHOU
}

British Medical fournal, 1976, 2, 1287-1289

\section{Summary}

The incidence of hypertension (mean diastolic pressure above $90 \mathrm{~mm} \mathrm{Hg}$ ) was evaluated in 85 patients with renal transplants whose follow-up ranged from 3 to 84 months. Bilateral nephrectomy had been performed in 80 recipients. The proportion of hypertensive subjects rose during the first three months, subsequently stabilised around $50-60 \%$ for up to five years, and then decreased slightly during the next two years. Over the years hypertension fluctuated so that one-third of the initially hypertensive patients became normotensive, and over one-third of the initially normotensive patients became hypertensive.

The main single aetiological factor was renal failure. A significant relation between steroid dosage and blood pressure was found in only a quarter of the hypertensive patients, and in another quarter no cause could be found.

\section{Introduction}

Although hypertension is a well-known complication of renal transplantation, its incidence and causes have been evaluated only in short-term studies soon after the operation. ${ }^{1-6} \mathrm{We}$ undertook this study, firstly, to assess the incidence of chronic hypertension up to seven years after renal transplantation and, secondly, to define its causal factors.

\section{Patients and methods}

From 1 January 1968 to 1 January 1973152 transplantations were performed in 142 patients. At three months $80 \%$ of the grafts were functioning. Immunosuppressive treatment consisted basically of

Renal and Transplantation Units, Cliniques Universitaires St-Pierre, Université de Louvain, Louvain, Belgium

C BACHY, MD, house officer, renal unit

G P J ALEXANDRE, MD, professor of surgery and chief of transplantation unit

C VAN YPERSELE DE STRIHOU, MD, professor of medicine and chief of renal unit azathioprine $(2 \mathrm{mg} / \mathrm{kg}$ body weight) and prednisolone. Actinomycin C and antilymphocyte globulins were given to some patients during the first six months.?

We studied 85 patients ( 52 males and 33 females) whose ages ranged from 7 to 55 years (mean 35.5). They had survived with their first graft for more than three months and were regularly followed up at our clinic. Patients were seen twice weekly during the first six months, weekly during the next six months, then twice monthly, and eventually monthly thereafter. A twice weekly schedule was resumed when rejection occurred.

The transplant originated from a cadaver in 82 cases and from a living relative in three cases. Bilateral nephrectomy was performed in 80 recipients.

Patients' charts were reviewed up to January 1976, so that the potential follow-up ranged from a minimum of 36 months to a maximum of 96 months. Blood pressure at the end of $1,2,3,6,12$, $18,24,36,48,60,72$, and 84 months was calculated by averaging the last five blood pressure readings obtained in the supine position. Mean diastolic pressures exceeding $90 \mathrm{~mm} \mathrm{Hg}$ without treatment or $85 \mathrm{~mm} \mathrm{Hg}$ with a diuretic and a salt-free diet were considered hypertensive. Mean diastolic pressures exceeding $100 \mathrm{~mm} \mathrm{Hg}$ without treatment or $95 \mathrm{~mm} \mathrm{Hg}$ with a diuretic and a salt-free diet were considered severely hypertensive.

Graft function was assessed by averaging the values of the last five serum creatinine determinations obtained at the end of each period. Total prednisolone dosage during each time interval was calculated for every patient.

Renal failure had been caused by chronic glomerulonephritis ( 50 patients), chronic interstitial nephritis including pyelonephritis and analgesic abuse (29 patients), polycystic kidneys ( 3 patients), malignant hypertension ( 2 patients), and renal tuberculosis (1 patient).

\section{Results}

INCIDENCE OF HYPERTENSION

The incidence of hypertension increased over the first three months and stabilised subsequently at around $50-60 \%$ for up to five years after transplantation. It fell thereafter to $40 \%$. Slightly fewer than half the hypertensive patients suffered from severe hypertension (table I).

\section{EVOLUTION OF HYPERTENSION}

The stability of hypertension was assessed in 58 patients whose grafts functioned for at least 36 months. Of 31 patients who were normotensive at three months, 14 had become hypertensive at 36 months. Conversely, of the 27 patients who were hypertensive at three months, nine had become normotensive at 36 months. 